\title{
“GEREJA DIBALIK DINDING": (Kajian Markus 7:24-30 dan Implikasinya bagi Pendidikan Multikultural di Indonesia)
}

\author{
Yuni Feni Labobar \\ Institut Agama Kristen Negeri Manado \\ yunilabobar@iakn-manado.ac.id \\ Diterima 15 Oktober 2018 \\ Disetujui 14 November 2018
}

\begin{abstract}
Abstrak
Tulisan ini bertujuan untuk menghasilkan pendidikan multikultural dengan mendialogkan Markus 7:24-30 yang berbicara tentang Yesus dan Perempuan Siro-Fenisia dengan dihadapkan dengan wacana multikultural dalam konteks Indonesia. Jenis penelitian yang digunakan adalah library research atau penelitian kepustakaan dan metode yang digunakan adalah analisis kualitatif melalui buku-buku tulisan James Banks dan Tabita Christiani. Melalui dialog analisis Teks Alkitab dan teori dari beberapa ahli ini dapat mengasilkan pendidikan multikultural dalam konteks Indonesia. Analisis terhadap teks Markus 7:24-30 merupakan salah satu teks Alkitab yang berbicara soal multikultural. Yesus berhadap dengan seorang perempuan Siro-Fenisia yang berbeda gender, agama, dan etnis dengan-Nya
\end{abstract}

Keywords: Pendidikan Kristiani, multikultural, Teks Markus 7:24-30.

\section{Abstract}

This paper aims to produce multicultural education by dialoguing Mark 7: 24-30 who talks about Jesus and SyroPhoenician Women by being confronted with multicultural discourse in the Indonesian context. This type of research is library research and the method used is qualitative analysis through books written by James Banks and Tabita Christiani. Through dialogue on the analysis of the Bible Text and theories from some of these experts, it can produce multicultural education in the Indonesian context. An analysis of the text of Mark 7: 24-30 is one of the biblical texts that talks about multiculturalism. Jesus confronted a Syro-Phoenician woman of different gender, religion and ethnicity from Him

Keywords: Christian education, multicultural, Mark 7: 24-30.

\section{LATAR BELAKANG}

Dalam era distruptif saat ini dapat membawa membawa dampak yang positif dan juga negative. Hal yang berhubungan dengan era ini adalah Post-Turth dimana kebenaran subjektif dapat dijadikan sebagai kebenaran objektif sehingga tidak memperhatikan apakah kepercayaan tersebut objetif atau tidak, atau sesuai dengan fakta-fakta. Kepercayaan dalam beragama tertentu misalnya tidak bisa dijadikan sebagai kebenaran bagi keberadaan agama yang lain. Setiap agama memiliki kepercayaan dan kebenaran tersendiri. Jika hal ini tetap dipertahankan maka yang terjadi adalah konflik beragama. Mengapa? Karena kebenaran atau kepercayaan pada pribadi dipakai bagi keberadaan yang lain. 
Penulis pernah mengikuti seminar Nasional yang diikuti oleh banyak akademisi. Kemudian ada pertanyaan yang dilontarkan oleh salah seorang peserta bahwa " Di salah satu desa $\mathrm{X}$ yang dominan beragama Kristen memiliki pabrik susu kuda yang dikelolah oleh Kristen yang menjadi pertanyannya adalah Bagaimana dapat menjamin bahwa susu kuda tersebut $100 \%$ halal jika dikelolah oleh porang Kristen? “ Mendengar pertanyan dari salah satu peserta ini hati saya begitu hancur karena orang Kristen dikatakan secara tidak langsung sebagai agama yang haram. Mengapa sampai saat ini begitu banyak kata-kata haram dan halal, kafir dan tidak selalu ada dalam hubungan beragama?

\begin{tabular}{llr}
\multicolumn{1}{c}{ Begitu } & banyak & kasus-kasus \\
kekerasan & yang & berbicara \\
mengatasnamakan & agama & karena
\end{tabular}
pemahaman beragama pada agamanya dipakai sebagai cara untuk menilai, mengkritisi kepercayaan agama lain. Menurut penulis hal-hal ini tidaklah menjadi masalah tapi jika dipaksakan akan mengganggu kenyaman yang lain. Ada beberapa contoh kebenaran bagi agama tertentu menilai agama lain. Misalnya di Aceh keharusan memakai jilbab dilakukan bagi seluruh warga masyarakat maupun yang non-Islam. Penggunaan Jilbab di Timur-Tengah dipakai oleh agama Abrahamik yakni Islam, Yahudi, Dan
Kristen. Tetapi jika simbol Jilbab ini dipakai dalam konteks Indonesia menjadi masalah bagi agama non-Islam. Sebab dalam konteks Indonesia Jilbab telah menjadi simbol agama Islam. Hal ini merupakan penerapan syariat Islam terhadap minoritas. Selain itu dalam dalam konteks yang lain upaya-upaya Kristenisasi terus dilakukan karena pemahaman secara harafiah terhadap kitab suci. Dalam Matius 28;19 “ Karena itu pergilah Jadikan semua bangsa muridku dan Baptislah dalam nama Bapa, anak dan Roh Kudus. Jika ayat ini dibaca secara harafiah, orang akan menganggap bahwa semua orang perlu untuk dikristenkan karena merupakan amanat yang diberikan. Apakah Tuhan seperti itu? Jika memang benar Tuhan adalah pencipta dan segala isinya itu artinya Ia juga tidak memihak atau hadir dalam satu agama tertentu dan mengabaikan agama yang lain. Ternyata ayat ini hanya diperuntukan bagi pendengar dalam injil Matius secara khusus bukan pada dunia secara global.

Kisah-kisah yang penulis ceritakan merupakan beberapa dari sekian banyak kasus-kasus yang terjadi merupakan pergumulan dari banyak orang Kristen maupun Islam yang merupakan orangorang yang minoritas di wilayahnya. Jika di satu tempat mayoritas Kristen maka yang minoritas pasti disudutkan, tidak ada 
kesempatan beribadah, tidak ada bangunan Ibadah dan sebaliknya jika mayoritas Islam maka dijalankan syariatkan Islam yang diberlakukan bagi seluruh warganya tanpa memandang latar belakang agamanya. Inilah adalah fakta yang terjadi di Negara kita. Inilah wajah-wajah keberagaman yang terjadi di Indonesia. Hal inilah yang perlu diperhatikan oleh gereja untuk mengeduksi jemaatnya tentang bagaimana caranya hidup beragam dalam konteks Indonesia yang begitu plural. Gereja harus mempertimbangkan keadilan dan kebebasan di tengah keberagaman. Maka melalui tulisan penulis akan mendialogkan teks Alkitab Markus 7:24-30 yang di beri judul oleh LAI "Perempuan Siro-Fenisia yang percaya". Bagaimana pembaca Alkitab melihat sesuatu yang berbeda dari teks bacaan ini bukan saja berbicara tentang apa yang dimaksud dengan "percaya disini" tetapi kita dapat belajar bahwa Yesus juga belajar dari yang lain. Yesus menghargai keberagaman. Yesus tidak memaksakan orang lain untuk mengikuti dia tetapi tetap ada dalam kepercayaan agama walau perempuan Siro Fenisia telah memperoleh kesembuhan dari Yesus.

Fakta yang didapatkan di dalam tubuh gereja adalah gereja memahami misi secara sempit. Gereja merasa sesuatu yang luar biasa jika ada orang pindah atau menjadi Kristen. Penulis berpikir bahwa dalam keberagaman terhadap agama lain gereja perlu untuk mengajarkan umatnya bahwa pendidikan multikulkultural yang sebenarnya harus seperti apa. Jika konteks kita adalah konteks yang majemuk gereja pun harus hadir sebagai gereja bagi sesama. Bukan arti misi secara sempit tentang penambahan jumlah tetapi gereja belajar dari Yesus yang tidak memaksakan kepercayaan lain untuk sama dengan apa yang kita percaya tetapi menghargai keberagaman sebagai anugerah Tuhan.

\section{Analisis Markus 7:24-30}

Dalam Perjalanan gereja selama berabad-abad bahkan sekarang gereja cenderung menganggap bahwa kebenaran itu hanya di dalam kekristenan. Bagaimana dengan agama lain? Jika kita mengganggap bahwa hanya orang Kristen saja yang benar? Jika Allah yang menciptakan seluruh umat manusia, berarti Allah pilih kasih sebab Allah hanya berpihak pada agama Kristen. Penulis melihat bahwa agama diyakini sekarang adalah agama warisan. Jika seseorang menjadi kristen karena orang tua nya beragama Kristen sebaliknya jika orang tua beragama Islam maka otomatis anaknya akan beragama Islam . Setiap orang yang dilahirkan ke dunia ini ia tidak bisa memilih dari dalam kandungannya Agama apa yang dipilih. Itu sebabkan penulis katakan bahwa agama adalah warisan. Lalu bagaimana mungkin 
manusia selalu saja mencela, menyakiti agama yang berbeda dengannya?

Percakapan di sekitar apakah kebenaran hanya ada di dalam Allah dan Allah itu hanya ada di dalam agama Kristen menjadi topik perdebatan pada masa pertumbuhan gereja. Para pelopor gereja, atau dalam tradisi Kristiani disebut bapakbapak gereja, sebelum Augustinus (354430) membangun pandangannya dengan prinsip: Tak ada keselamatan yang ditemukan di luar gereja (extra ecclesiam nulla salus). Berdasarkan prinsip ini Irenius (130-200), seorang teolog dan pengarang buku Against Herecies, menyatakan bahwa gereja adalah sumber Roh Allah dan segala karunia. ${ }^{1}$ Masih dalam hubungan extra ecclesiam nulla salus, Origenes (185-254) memahami gereja sebagai sumber kebenaran. Gereja dalam pandangannya dirupakan dalam gambaran rumah Rahab (Yosua 2:1-25). Dari rumah pelacur itu dua pengintai Israel akhirnya selamat dari kejaran pasukan raja Yerikho. ${ }^{2}$ Seprianus (m. 258), uskup Cartago - Afrika Utara dan penulis buku The Unity of the Catholic Church, menyatakan kepada orang-orang yang menyimpang dari agama, bahwa di sana hanya ada satu rumah Allah, dan di

\footnotetext{
${ }^{1}$ Veli-Matti Kärkkäinen, An Introduction to the Theology of Religions: Biblical, Historical,
}

sana tidak ada keselamatan bagi tiap-tiap orang kecuali di dalam Gereja.

Berdasarkan Fakta-fakta sejarah dari bapa-bapa gereja tentang Kekristenan penulis akan mengajak kita belajar dari Yesus yang berjumpa dengan seorang perempuan Fenisia. Memang di dalam Alkitab tidak ada frasa yang berbicara secara langsung tentang keberagaman agama. Namun realitas tentang keberagaman agama ada ada di dalam Alkitab. Ada banyak cerita Alkitab yang berbicara tentang Yesus ketika berhadapan dengan orang yang berada di luar lingkungannya. Hal ini dapat menjadi suatu model bagi keberagaman agama di Indonesa ketika berhadapan dengan orangorang yang berbeda.

LAI memberikan judul pada teks bacaan ini "Perempuan Siro-Fenisia yang percaya" padahal kalau melihat pada akhir bacaan ini tak tertulis apakah perempuan ini mengikuti Yesus dan percaya setelah penyembuhan yang Yesus lakukan bagi anaknya. Hal yang kedua kata Tuhan (ay.28) dalam bahasa aslinya (Yun.ku,rie)artinya tuan. Itu artinya kata ini tidak menunjukkan keilahian Yesus sama seperti LAI yang memberi terjemahana "Tuhan". Itu berarti bahwa perempuan ini

and Contemporary Perspectives (Downers Grove, Ill.: InterVarsity Press, 2003), h. 63.

${ }^{2}$ Kärkkäinen, h. 63. 
tetap menjadi orang Kanaan dengan kepercayaan yang ia miliki setelah kisah penyembuhan.

Seperti yang dijelaskan oleh Larry W. Hurtado Gestur seperti di atas yang digambarkan dengan menggunakan kata

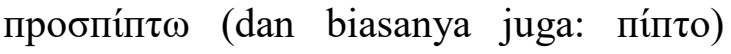
menurut konteks pada masa itu, seperti yang dikemukakan Hurtado, tidak mengharuskan kesimpulan bahwa perempuan itu mengakui keilahian Yesus. Bagi Hurtado, kata yang lebih teknis menggambarkan gestur penyembahan terhadap keilahian (cultic whorship) adalah proskunew. ${ }^{3}$ Itulah sebabnya, ketika Matius 15:25 menggambarkan gestur perempuan ini ("perempuan kanaan" sebagai sebutan lain dari "perempuan Siro-Fenesia") dengan kata proskunew, Hurtado menyimpulkan bahwa Matius memfungsikan kata itu untuk "foreshadowings of the exalted reverence of Jesus familiar to his Christians readers in their collective worship. ${ }^{4}$

${ }^{3}$ Larry W. Hurtado, How on Earth Jesus Become God?Historical Questions about Earliest Devotion to Jesus (Grand Rapids, Michigan: Eerdmans, 2005), 140-141. Menurut Hurtado, istilah yang lebih khusus menggambarkan gestur dalam rujukan kepada sikap penghormatan akan keilahian, walau tidak selalu begitu. Konteks tetap harus dipertimbangkan untuk membuat kesimpulan ini; bnd. James D.G. Dunn, Did the First Christians Worship Jesus? The New Testament Evidence (Louisville, Kentucky: Westminster John Knox Press, 2010), h.8-12.
Kata "iman" memang tidak muncul dalam narasi ini, juga seperti yang dinyatakan Skinner: “...Yesus memberi kredit untuk logoj (argumen), dan bukan pistij(iman)nya". 5 Namun presentasi Markus mengenai kegigihan, gestur, permohonan, dan argumen, serta apresiasi Yesus terhadapnya persis seperti yang dikemukakan Theissen: "the woman not only evokes the image of the faithful dog in her reply, she behaves like a 'devoted dog. ${ }^{6}$ Sebuah kombinasi yang sejati antara "percaya" ( trust) dan "pengertian" (understanding) membuat perempuan ini layak disebut sebagai perempuan beriman. ${ }^{7}$ Kata "percaya" yang diberi judul oleh LAI tidak menunjukkan bahwa perempuan Siro Fenisia percaya kepada Yesus karena kisah pembuhan yang dilakukan oleh Yesus kepada anaknya. Tetapi nampak pada sikap dari perempuan ini

Kisah ini diawali dengan perjalanan Yesus menuju ke Tirus. Tirus adalah sebuah daerah yang berbatasan langsung dengan Galilea. Daerah ini jelas adalah God?, 146.

${ }^{4}$ Hurtado, How on Earth Jesus Become

5 Skinner, "'She Departed to Her House': Another Dimension of the Syrophoenecian Mother's Faith in Mark 7:24-30," h. 15.

${ }^{6}$ Theissen, The Gospels in Context, 80.

${ }^{7}$ Bnd. Telford, The Theology of the Gospel of Mark, 101, menyatakan: "Faith for Mark, however, as I have elsewhere argued, is connected with understanding, and understanding with the true significance of Jesus' person and mission." 
daerah orang kafir. $^{8}$ Melalui kehadiran Yesus di tanah orang kafir. Injil Markus ingin menunjukkan bahwa Yesus terbuka dan memiliki belas kasihan kepada orang kafir. Lalu datanglah seorang Perempuan Yunani Sirio-Fenesia yang memohon kepada Yesus untuk memberikan kesembuhan bagi anaknya. Siro-Fenisia adalah daerah yang terletak di antara Tirus dan Sidon di Roma. Perempuan ini adalah seorang Yunani, yang dapat juga dikatakan seorang Kanaan karena pada masa itu Kanaan termasuk dalam daerah Tirus dan Sidon. Menurut Antone dalam klasifikasi yang dibuat orang Yahudi, perempuan itu adalah seorang kafir (gentile) atau bukan orang Yahudi. Seorang penyembah berhala, orang asing terhadap kebudayaan mereka dan berada di luar perjanjian Allah mereka. ${ }^{9}$

Lalu selanjutnya apa yang dikatakan Yesus ketika perempuan ini meminta Yesus untuk menyembuhkan anaknya. "Biarlah anak-anak kenyangkenyang dahulu, sebab tidak patut mengambil roti yang disedikan bagi anakanak. dan melemparkan kepada anjing". Kalimat yang Yesus ajukan begitu kasar. Ini mengungkapkan penolakan Yesus terhadap permintaan perempuan ini. Frasa "anak-anak" ini ditunjukkan kepada orang

8 Josephus, Against Apion, 1.70, in Josephus: The Complete Works (Grand Rapids, Michigan: Christian Classics Ethereal Library, n.d.).
Yahudi, sedangkan kata "anjing" ini ditunjukkan bagi orang non-Yahudi. Itu artinya bahwa berkat Allah dalam pemahaman orang Yahudi waktu itu, hanya ditunjukkan bagi orang Yahudi. Apakah dengan perkataan Yesus yang kasar ini membuat perempuan ini diam? Apalagi ia sudah direndahkan dihina bersama bangsanya. Perempuan ini begitu cerdik berani membalas pernyataan Yesus dengan mengatakan bahwa "Benar Tuhan. Tetapi anjing yang di bawah meja juga makan remah-remah yang dijatuhkan anak-anak". Seperti yang dikatakan oleh Hope S. Antone yang mengutip Elisabeth Schussler Fiorenza:

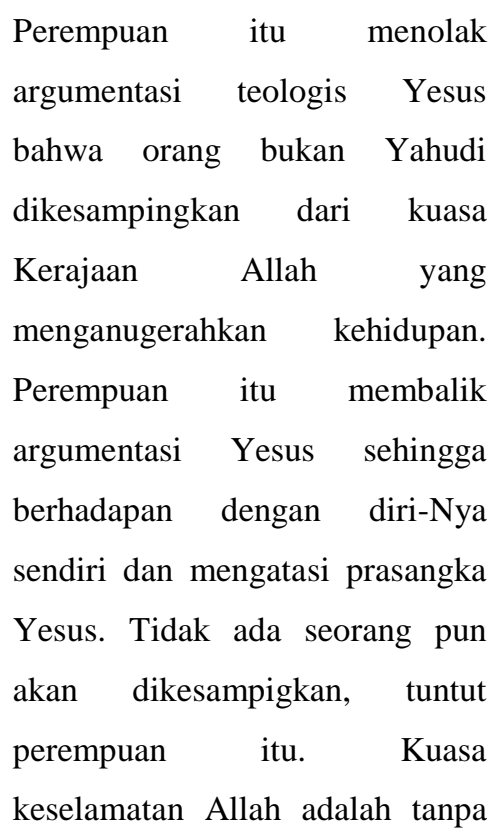

9 Hope S. Anton, Pendidikan Kristiani Kontekstual, (Jakarta: BPK Gunung Mulia, 2010), h. 82 
batas, dan argumentasi perempuan

itu menang... 10

Wanita ini mendatangi Yesus (7:2526), mengklaim keberlimpahan berkat Allah (7:28), dan disuruh pulang oleh Yesus dengan mendapatkan keberlimpahan berkat itu (7:29-30). Dan kedua para murid sendiri yang menyaksikan sendiri betapa berlimpahnya berkat Allah itu dicurahkan (6:30-43), namun mereka masih tetap tidak mengerti dan hati mereka tetap degil (6:52). Bahkan setelah peristiwa ini kemudian Yesus menyembuhkan orang-orang di Dekapolis dan memberi makan 4000 orang di daerah itu, para murid masih mendapatkan tegoran dari Yesus atas alasan yang sama (8:17). Wanita ini hanya mendengar tentang Yesus, mendapatkan pengajaran Yesus tentang misi-Nya (sesuatu yang tidak dikatakan sebelumnya mengenai para murid) dan ia menegaskan apa yang tidak dipahami oleh para murid Yesus sendiri (7:28; bnd. 4:20). ${ }^{11}$ Itu artinya bahwa perempuan ini bukan orang biasa, ia tentu sangat cerdas berani beradu argumen dengan Yesus. Murid-murid adalah pengikut setia Yesus saja tidak paham apa

10 Hope S. Anton, Pendidikan Kristiani Kontekstual, (Jakarta: BPK Gunung Mulia, 2010), h. 80

${ }^{11}$ Iverson, Gentiles in Gospel of Mark, 54, menyebutkan juga bahwa wanita itu bahkan memiliki pengertian yang melebihi para pemimpin yang dilakukan oleh Yesus sedangkan perempuan Siro-Fenisia ia paham betul bahwa Allah memiliki berkat yang melimpah dan perempuan ini walau berbeda dengan Yesus, ia berhak untuk menerima berkat tersebut.

Beberapa orang teolog mengklaim bahwa penggunaan kata "anjing" yang mengacu pada orang bukan Yahudi seharusnya seharusnya diletakkan dalam konteks rumah tangga miskin, di mana keluarga dan binatang peliharaan berada dalam satu ruang. Jadi, mereka mendesak bahwa kata "anjing" benar-benar mengacu pada binatang peliharaan di dalam rumah tangga yang hidup bersama anak-anak, ketimbang sebagai hewan tersesat atau anjing liar. ${ }^{12}$

Ada kata remah-remah (ay.28) disini menunjukkan bahwa perempuan ini sadar tentang keberadaan dirinya sebagai orang kelas nomor dua. Ia mengakui akan keberadaan dirinya dan masyarakatnya dengan sebutan anjing. Perempuan ini sadar betul Ia tidak berhak untuk menerima roti karena status etnisnya sebagai orang kafir. Namun ia mengklaim dirinya sebagai orang khafir yang juga berhak untuk mendapatkan kebaikan kerajaan sorga yang

Yahudi yang seharusnya lebih paham tentang karya Allah (bnd. 2:7, 16, 24; 3:2, 22; 7:1-13)Edwards, The Gospel According to Mark, 221.

12 Hope S. Anton, Pendidikan Kristiani Kontekstual, h. 81 
memang bisa diterima oleh siapa saja. Pernyataan dari Yesus membuat Yesus pun memikirkan ulang kembali pemahamannya terhadap permohonan yang beralasan dari perempuan tersebut dan pada akhirnya perempuan ini pun menang terhadap argumentasinya (ay.28).

Lalu pertanyannya apakah yang membuat sehingga Yesus memberikan kesembuhan terhadap perempuan itu, padahal sudah jelas perempuan ini tidak percaya pada Yesus dan dianggap menyembah berhala? Yesus memberikan kesembuhan bukan karena iman perempuan ini, seperti pada pandangan populer umumnya bahwa ia disembuhkan karena imannya tapi karena kerendahan hati dari perempuan ini. Kalau bacaan ini dihadapkan dalam konteks kita sekarang mungkin setelah kisah penyembuhan tadi kita melakukan baptisan dan menyuruh perempuan untuk masuk dalam kepercayaan iman kita. Tetapi apakah setelah kisah itu Yesus menyuruh perempuan itu untuk menyembah-Nya atau mengakuinya sebagai Tuhan dan juru selamat? Tidak sama sekali. Tidak ada kisah selanjutnya yang menceritakan bahwa perempuan ini mengikuti atau Mark, 54.

${ }^{13}$ Bnd. Iverson, Gentiles in the Gospel of 54.

${ }^{14}$ Iverson, Gentiles in the Gospel of Mark, percaya pada Yesus. Yang hendaak ditekankan disini bukan orang atau atau kepercayaannya tetapi ketika seseorang mengalami kasih Allah dalam kehidupannya.

Struktur khiastik Markus 7:24-31 ,fokus dari narasi ini adalah dialog Yesus dan perempuan Siro-Fenesia tersebut,yang terjadi dalam konteks eksorsisme. ${ }^{13}$ Seperti yang dikemukakan Iverson, ini adalah satusatunya catatan mengenai eksorsisme jarak jauh yang dicatat dalam Injil Markus, berbeda dengan catatan mengenai eksorsisme lainnya (bnd. 1:25, 31, 41; 2:5, $11 ; 3: 5 ; 4: 39 ; 5: 8,41 ; 9: 25) .{ }^{14}$ namun yang jelas "ia pulang tanpa pendamping atau kehadiran Yesus sebagai jaminan dari validitas janji-Nya. Kebersediaannya untuk memegang kata-kata Yesus...dan kembali ke rumah, ia menampilkan iman. ${ }^{15}$ Aksi perempuan ini memperlihatkan bahwa perbedaan-perbedaan seperti Yahudi/khafir, anak-anak/anjing, laki atau perempuan. Perbedaan-perbedaan yang ada jangan ditolak atau dihindari melainkan perbedaan-perbedaan yang ada harus dihargai.

Apabila kita tertutup dengan keberadaan di sekitar, tidak menerima

\footnotetext{
15 Skinner, "'She Departed to Her House': Another Dimension of the Syrophoenecian Mother's Faith in Mark 7:24-30," 21; bnd. Gould, A Critical and Exegetical Commentary on the Gospel According to St. Mark, 137.
} 
perbedaan-perbedaan yang ada serta hidup dalam pandangan-pandangan dan kebiasaan yang salah, maka kita hidup menjadi orang-orang yang tidak menghargai dan menilai orang lain berdasarkan ukuran mereka masingmasing, karena menurut kita pandangan kita lah yang paling benar. Ingat bahwa Kasih Allah lebih luas dari pada apa yang benar-benar dipahami orang.

Dari perjumpaan antara Yesus dengan perempuan Siro-Fenisia ini ada dampak yang begitu besar. Kita harus mengakui bahwa ketika mengalami perjumpaan dengan orang lain selalu saja ada perbedaan. Tanpa perbedaan, kita tidak akan pernah mendapatkan pelajaran dengan adanya perjumpa tersebut. Karena dengan adanya perbedaan itulah, kita bisa belajar segala sesuatu yang dimilki oleh yang lain yang tidak kita miliki. Kesadaran akan perbedaan ini perlu adanya sikap rendah hati untuk mendengar persektif orang lain sama seperti perempuan Siro Fenesia. Hendaklah kita sadar bahwa setiap orang memiliki kebenaran-kebenaran tersendiri oleh karena itu kita belajar dari perjumpaan adalah sesuatu yang penting. Perjumpaan akan membawa kita untuk mengklarifikasi anggapan kita tentang pandangan orang lain. Seperti perempuan Siro-Fenesia ini

16 Hope S. Anton, Pendidikan Kristiani Kontekstual, (Jakarta: BPK Gunung Mulia, 2010), h. 86 yang akhirnya mendapatkan klarifikasi tentang diri Yesus yang memilki kasih melebihi batas-batas perbedaan yang ada. Klarifikasi itu penting, karena prasangka yang tidak diklarifikasi dengan benar akan menjadi pemicu masalah dalam komunitas.

\section{Dialektika Markus Markus 7:24-30 dan Pendidikan Multikultural di Indonesia}

Pendekatan dialogis adalah suatu pendekatan yang mengakui keabsahan pengalaman keagamaan yang berbeda dan beragam dari semua orang dan menyingkirkan semua klaim ekslusif terhadap kebenaran satu tradisi agama. Dalam pendekatan ini, setiap agama patut dikasihani dan dihargai. Semua agama mengandung unsur pembebasan dan juga unsur penindasan, sementara tugas hermeneutika adalah mengumpulkan aspek-apek yang membebaskan untuk menciptakan harmoni dan perubahan sosial bagi semua orang. ${ }^{16}$

Banks memberi pengertian yang lebih baru bahwa antara kultur dan agama tidak perlu dibedakan, agama bagian dari kultur. Seperti yang dikatakan Banks bahwa Pendidikan Multikultural bertujuan untuk menciptakan pendidikan yang setara 
bagi kelompok yang berbeda, baik dari latar belakang gender, ras, etnis, kelas sosial, bahasa, agama dan budaya. ${ }^{17}$ Dalam rangka belajar tentang agama lain, PK bertujuan memberi apresiasi dan merayakan perbedaan, sebagai bentuk penerimaan terhadap "liyan". Ini lebih dari upaya mencari kesamaan. Ini membutuhkan keterbukaan untuk melihat perbedaan dan mendorong kesetaraan. Mempelajari agama lain juga berarti memahami kemajemukan dalam setiap agama. Ini menolong umat untuk memahami ambivalensi dari agama, termasuk kekristenan, sehingga umat tidak terkejut atau kecewa ketika agama digunakan untuk mempromosikan kekerasan daripada perdamaian. ${ }^{18}$ Gereja perlu mengajarkan umat tentang pendidikan multikultural apalagi dengan konteks Indonesia yang begitu beragam. Pendidikan multikultural dilakukan di dalam jemaat mulai dari anak hingga dewasa sehingga perbedaanperbedaan yang ada bukan dijadikan sebagai ancaman tetapi sebagai kekayaan yang perlu disyukuri bersama. Biasanya di dalam jemaat cara pengajaran tradisional selalu dilakukan di gereja seperti pembacaan Alkitab kemudian relevansi.

\footnotetext{
${ }^{17}$ James Abanks \& Mcgee Banks Cherry A (eds),Multicultural Education: Issues and Perspectives(New York: John Willey \&Sons, 2001), 25

18 Tabita Kartika Christiani, "Christian
} Education for Peace Building in the Pluralistic
Umat tidak diajak untuk berefleksi terhadap realitas yang keberagaman yang terjadi. Begitu banyak kasus-kasus yang ada di dalam konteks Indonesia tentang masalah yang berhubungan gender, ras, etnis, bahasa, agama dan budaya. Pendidikan Kristiani dilakukan agar nara didik diajarkan tentang keberagaman agama lain, belajar terbuka.

Berhadapan dengan cerita Yesus dan Perempuan Siro-Fenisia, Yesus telah memberi contoh pendidikan kultural yag dijelaskan oleh Banks. Yesus menciptakan pendidikan yang setara bahwa anugerah Allah bukan saja diterima untuk orang Yahudi tetapi orang di luar Yahudi. Perempuan Siro-Fenisis berbeda Gender, ras, etnis, kelas sosial, kepercayaan. Yesus menerima perempuan ini walaupun awalnya ia dan bangsanya disamakan dengan anjing. Yesus merupkan orang yang terbuka tetapi juga setara tentang anugerah Allah. Yesus belajar dari kepercayaan agama lain. Yesus mengakui akan kerendahan hati dari perempuan ini.

Yesus telah memberikan suatu teladan dari apa artinya menjadi seorang pluralis walaupun tetap menjadi seorang

Indonesian Context, ( Zuric: LIT VERLAG, 2009) Dalam Carl Sterkens, Muhammad Machasin, Frans Wijsen (ed.). Religion, Civil Society and Confl ict in Indonesia, h. 188 
Yahudi yang benar-benar setia, maka pengikut-pengikut Yesus sekarang ini juga berarti bahwa mereka pun dapat menjadi seorang pluralis walaupun tetap menjadi orang Kristen yang benar-benar setia dengan imannya. Seorang pluralis bagaimanapun juga adalah seorang yang berakar dengan baik dalam tradisi imannya, tetapi terbuka dan mampu mengakui orangorang yang berasal dari tradisi agama lain. Sikap ini dimungkinkan ketika seorang sejati mengakui bahwa kasih Allah lebih luas daripada apa yang benar-benar dipahami orang. Ini hanya bersandar pada pengetahuan bahwa Allah mengasihi dan berkomitmen untuk menyelamatkan semua orang kepunyaan-Nya. ${ }^{19}$

Pendidikan Kristiani mengajarkan tradisi iman pertama yang dicatat dalam Alkitab sehingga orang-orang mengenali identitas Yesus dan turut mencari sumbersumber untuk memahami kehendak Allah dalam kehidupan sehari-hari. Selanjutnya orang-orang percaya melakukan refleksi teologis ketika menghadapi isu-isu dan akan mengambil keputusan tentang bagaimana hidup dalam kondisi demikian. Pendidikan Kristiani perlu menyediakan ruang terbuka bagi mereka yang

19 Hope S. Anton, Pendidikan Kristiani Kontekstual, (Jakarta: BPK Gunung Mulia, 2010), h. 89

20 Jack L Seymour (ed), Memetakan Pendidikan Kristiani Pendekatan-Pendekatan mempelajari tradisi iman dan memperhadapkan tradisi iman itu dengan masalah-masalah kehidupan serta berusaha untuk hidup setia kepada Allah. Maka Seymour merumuskan bahwa Pendidikan Kristiani adalah sebuah percakapan kehidupan, sebuah usaha untuk menggunakan sumber iman dan tradisi kultural dalam menghadirkan masa depan yang adil dan berpengharapan ${ }^{20}$. Christiani menambahkan bahwa Pendidikan Kristiani bukan sekadar kegiatan meneruskan dogma dari waktu ke waktu dan menghafalkannya, melainkan mempertemukan ajaran-ajaran gereja itu dengan kehidupan masa kini dalam percakapan, yang mengarah ke masa depan yang adil dan penuh pengharapan. ${ }^{21}$ Salah satu tradisi iman adalah kitab suci melalui kitab suci umat diajarkan untuk membaca Alkitab secara berbeda dari kacamata keberagaman. Memahami kehendak Allah secara berbeda.Perlu adanya refleksi bersama terkait dengan kasus-kasus kekerasan yang mengatasnamakan agama.

Dalam berefleksi teologi tentang cerita "Perempuan Siro-Fenisia yang Percaya" menurut Antone Sebagai orang Kristen mungkin kita lebih senang

Menuju Pembelajaran Jemaa. (Jakarta: BPK Gunung Mulia, 2016),h. 13

21 Tabita Kartika Christiani, Pendidikan Kristiani Berbasis Multikultural (Ungaran: Semarang, 2018), h. 54. 
membayangkan dan mengasumsikan bahwa pada akhirnya perempuan itu dan putrinya tidak dapat tidak menjadi Kristen (Yang menjadi tidak logis karena Yesus sendiri bukan orang Kristen). Namun, ini adalah proyeksi yang menyedihkan dari pola pikir warisan pekabar injil yang tidak pernah melewatkan sedikit pun kesempatan untuk "mempertobatkan" orang lain ke dalam agama Kristen. Daripada mengasumsikan bahwa perempuan itu menjadi Kristen, mengapa kita tidak berpikir dan menerima fakta bahwa ia dapat melanjutkan kehidupan dengan apa pun bentuk ibadah dan agamanya? Tampaknya bagi Yesus, yang penting bukan orang atau agamanya, tetapi sampai sejauh mana orang lain mengalami anugerah kesembuhan Allah melalui diri-Nya. ${ }^{22}$ Upaya misi tradisional masih terus dipelihara oleh gereja dan tidak bisa memungkiri hal ini. Gereja berupaya untuk melakukan penambahan jiwa supaya jumlah agama kristen makin bertambah banyak. Apakah setelah kisah itu perempuan Siro-Fenisia menjadi Kristen? Tidak dijelaskan dalam teks bacaan bahwa perempuan ini mengikuti Yesus. Itu artinya perempuan ini tetap menjadi orang kanaan dengan iman dan kepercayaanya yang berbeda dengan Yesus.

22 Hope S. Anton, Pendidikan Kristiani Kontekstual, (Jakarta: BPK Gunung Mulia, 2010), h. 87
Menurut Christiani, memberi apresiasi dan merayakan keragaman tidaklah cukup. Umat Kristen juga perlu melakukan dialog lintas iman. Dalam tataran akademis, temanya bisa berhubungan dengan perdamaian dan keadilan. Namun untuk kaum awam, mereka perlu dialog kehidupan, termasuk dalam hidup pertetanggaan. Hidup bertetangga berarti mempedulikan dan menolong satu sama lain. Masyarakat belajar tentang nilai cinta kasih, keramahan, kebaikan, dan kemurahan. Umat Kristen perlu hidup dalam pertetanggaan pluralistik yang lebih luas: mencakup orang-orang dari agama lain. Persahabatan yang kuat dapat mengembangkan keterbukaan untuk menerima yang lain dan akan mengatasi stigma, penilaian buruk, serta diskriminasi. Dialog memerlukan respek, kejujuran, kritik, dan keterbukaan. Umat dapat menemukan persamaan, tetapi sangat penting untuk menyadari keberbedaan di antara mereka. Menemukan dan mengakui perbedaan -perbedaan secara tulus akan mempromosikan upaya perdamaian. Dalam dialog, orang tidak perlu khawatir untuk kehilangan identitas agama mereka.. ${ }^{23}$ Dialog lintas iman untuk kaum awam menurut penulis sulit dilakukan di

23 Tabita Kartika Christiani, "Christian Education for Peace Building in the Pluralistic Indonesian Context, h. 188-190 
daerah bekas konflik seperti yang terjadi di Ambon. Setelah konflik Ambon, desa yang sebelumnya didiami oleh dua agama yakni Islam dan Kristen tidaklah seperti dahulu. Jika menyebutkan salah satu nama desa di Ambon orang sendirinya akan tahu bahwa desa $\mathrm{X}$ adalah desa Kristen dan desa Y adalah desa Islam. Penyebutan nama Desa telah menjadi menjadi identitas masingmasing agama. Bagaimana orang akan belajar keberagaman terhadap agama lain, jika dalam kehidupan bertetangga umat hanya tinggal dengan orang yang memiliki agama yang sama. Umat tidak akan bisa belajar jika ia tidak berjumpa dengan agama lain.

Ada beberapa hal yang dikemukakan oleh Antone tentang melihat bagaimana Yesus memahami suatu perluasan perspektif dalam memahami suatu komunitas yang sedang berdialog dengan kemajemukan. Pertama, bagaimana Yesus menjadi sadar pada realitas kemajemukan di samping juga partikularNya sebagai seorang yahudi dan juga Israel. 24 Jika kita melihat akan sikap Yesus terhadap perempuan ini Apakah Yesus bersikapAcuh? Tidak mau pedulikan perempuan yang berbeda dengannya? Dalam konteks keberagaman di Indonesia ada oknum-oknum yang menolong lain

${ }^{24}$ Hope S. Anton, Pendidikan Kristiani Kontekstual, (Jakarta: BPK Gunung Mulia, 2010), h. 87 harus melihat dahulu latar belakang dari orang tersebut. Agamanya apa?Darimana berasal? Hal-hal ini masih ada dalam kehidupan keberagaman di Indonesia. Kalau apa yang dilakukan Yesus terhadap perempuan Siro-Fenisia menggunakan konteks kita sekarang maka jelaslah Ia tidak akan menolong. Alasannya karena perempuan jelas adalah orang kafir yang menyembah allah lain. Dia berasal dari Kanaan bukan Yahudi.

Dialog antar agama membutuhkan aksi konkrit. Jadi bukan hanya pertukaran pikiran tetapi juga dialog karya, praksis. Dalam PK untuk upaya perdamaian, umat Kristen perlu melampaui batas, melampaui dinding gereja dan bekerja bersama dengan umat beragama lain untuk perdamaian dan keadilan. PK adalah suatu proses dari aksi dan refleksi. Setelah aksi bersama, dilanjutkan dengan refleksi bersama atas aksi yang telah dilakukan bersama tersebut. Proses ini menolong semua pihak untuk lebih sensitif dan empatis kepada orangorang yang menderita di bawah penindasan dan ketidakadilan. Ini juga menolong umat untuk memiliki solidaritas dengan orangorang tersebut dalam perjuangan mereka untuk perdamaian dan keadilan. Bekerja dengan umat beragama lain dapat dilakukan dengan berbagai aktivitas sosial. 
Komunitas tersebut dapat mencegah agar konflik tidak terjadi lagi. Orang-orang dapat meningkatkan suara mereka dan menjadi terlibat dalam pembuatan keputusan politis yang mempromosikan perdamaian dan keadilan. Dalam hubungannya dengan konflik antar agama, mereka dapat belajar tentang dan membagikan perhatian mereka untuk mengubah masyarakat lebih damai dan adil. 25

Ambon adalah salah daerah konflik yang terjadi selama 11 tahun (tahun 19992011). Konflik ini tentu membawa dampak yang tidak baik bagi kedua agama besar yakni Islam dan Kristen. Banyak sekali dialog-dialog yang dilakukan untuk memperbaiki hubungan yang rusak. Salah satunya melalui musik untuk menjalin hubungan antar para pemuda kedua agama.Tahun 2018 kemarin di Ambon pernah melakukan ibadah bersama antara Islam dan Kristen di dalam gedung Gereja. Pembacaan Alkitab dan pembacaan AlQuran, Khotbah dilakukan secara bersamasama di dalam gedung gereja. Ketika hal ini terjadi penulis melihat begitu banyak komentar yang dilakukan oleh kedua agama baik pihak Islam maupun Kristen. Salah satu alasannya yaitu "kecuali tidak ada tempat ibadah bagi kedua agama. Islam

25 Tabita Kartika Christiani, "Christian Education for Peace Building in the Pluralistic Indonesian Context, h. 190-192 memiliki mesjid, kristen memiliki gedung gereja. Kenapa sampai ibadah bersama dilakukan? "Penulis melihat bahwa Ambon sudah mulai terbuka terhadap keberagaman agama yang lain. Dialog bukan hanya sekedar dialog bersama untuk bertukar pikiran mempertemukan kedua agama. Tetapi Ambon sudah ada pada dialog transformatif dimana ibadah dilakukan secara bersama-sama baik itu dari pihak Islam dan Kristen. Penulis melihat bahwa antara kedua pemuka agama haruslah melakukan sosialisasi terlebih dahulu sebelum dilakukan ibadah bersama antara kedua agama. Mengapa? Karena jika hal ini tidak dilakukan umat yang belum terbiasa dengan ibadah bersama antara kedua agama. Bekas luka akibat konflik selama 11 tahun tentu masih dalam ingatan mereka. Nampaknya orang takut berdialog karena takut identitas agama mereka hilang. Kecurigaan ini masih terus dirasakan apalagi di wilayah daerah bekas kerusahan yang mengatasnamakan agama. Misalnyadi Poso dan Ambon. Dialog dilakukan bukan supaya terjadi peleburan antara dua agama yang berbeda. Dialog dilakukan supaya kecurigaan-kecurigaan yang ada dapat terminimalisir, untuk menyadari akan perbedaan. 
Menurut Christiani, dalam konteks Indonesia yang plural, kurikulum tersebut tidak cukup, sebab terbatas pada personal dan tidak berhubungan dengan konteks Indonesia yang membutuhkan perdamaian. Murid hanya tahu dogma Kristen tanpa menghubungkan dengan konteks Indonesia. Selanjutnya, ia mengusulkan model PK yang mempromosikan perdamaian dalam pengertian yang lebih luas, yakni shalom bagi semua ${ }^{26}$ Dalam konteks bergereja di Indonesia khususnya untuk gereja arus utama.Dogma dianggap sebagai wahyu Allah yang bersifat turun temurun. Gereja lebih mengarahkan pandangan pada dogma dibandingkan begitu banyaknya masalah yang terjadi dalam konteks Indonesia khususnya yang berhubungan dengan isu SARA.

Christiani menggunakan gambaran Seymour tentang suatu dinding-_di balik dinding" dan "pada dinding"sebagaimana telah dijelaskan sebelumnya. Namun ia mengatakan bahwa dua istilah tersebut tidak cukup karena hanya menggambarkan formasi iman dan dialog lintas iman. Adalah perlu untuk memperluas gambaran tersebut dengan ekspresi "beyond the wall", 'melampaui dinding', untuk menggambarkan PK yang menolong murid bekerja bersama dengan

26 Tabita Kartika Christiani, "Christian Education for Peace Building in the Pluralistic Indonesian Context, h. 181 umat beragama lain demi membangun perdamaian dan keadilan. ${ }^{27}$ "Melampaui dinding" merupakan cara dialog yang baik. Mengapa? Karena gereja hanya mengarahkan pandangan pada "dinding" tanpa melihat sekitar secara luas. Gereja lebih fokus pada anggota jemaat sehingga lupa bagaimana caranya menjadi gereja bagi sesama.

PK “di balik dinding” ditempatkan dalam komunitas Kristen. Formasi iman didasarkan pada ajaran Kristen, tetapi bukan hanya mengulang doktrin gereja melainkan berbagi refleksi teologis dalam pengalaman hidup. Umat membaca teks Alkitab dalam terang konteks hidup mereka. Sering kali, umat memahami bahwa hanya ada satu makna yang benar saat membaca teks, yakni makna yang dijelaskan para ahli biblika. Hal ini harus dikoreksi. Memang, para pakar membantu umat untuk memahami konteks saat Alkitab ditulis. Namun mendalami secara tajam tentang bagaimana Alkitab bermakna bagi kehidupan umat, adalah tugas umat. Umat perlu meyakini penyataan Allah melalui dialog antara teks dengan konteks hidup mereka, demikian juga sebaliknya. Proses hermeneutik ini memampukan umat untuk membaca Alkitab dengan perspektif konteks kehidupan mereka sendiri. Melalui

27 Tabita Kartika Christiani, "Christian Education for Peace Building in the Pluralistic Indonesian Context, h. 183 
pendekatan ini, Alkitab menjadi teks pengharapan, yakni kebebasan bagi semua yang tertindas, semua yang terpinggirkan. Umat Kristen juga belajar teks-teks yang berisi kekerasan dan membaca secara utuh .$^{28}$ Membaca Alkitab dari terang konteks hidup umat merupakan cara yang dilakukan oleh gereja untuk mengedepankan pengalaman yang terabaikan oleh gereja. Orang cenderung berpikir bahwa yang benar adalah makna teks dari ahli biblika tetapi makna teks dari umat adalah bagaimana cara umat memaknai teks berdasarkan realitas kemajemukan yang mereka alami. Umat bisa melihat bahwa kasih Allah melampaui apa yang orang pikirkan bukan hanya terbatas pada orang Kristen tetapi pada seluruh ciptaan.

Umat Kristen juga berhubungan dengan konflik antar agama. Apa yang Alkitab katakan kepada mereka ketika gereja dirusak? Bagaimana umat Kristen, korban kekerasan, dapat bereaksi sesuai kehendak Tuhan? Apa sikap etis yang seharusnya dilakukan? Membaca Alkitab dalam konteks plural memerlukan dialog antara Alkitab dan konteks. Ini juga bicara tentang umat beragama lain. PK perlu menguji "Apakah firman Tuhan dalam

28 Tabita Kartika Christiani, "Christian Education for Peace Building in the Pluralistic Indonesian Context,h. 184

29 Tabita Kartika Christiani, "Christian Education for Peace Building in the Pluralistic Indonesian Context, h. 185 masyarakat majemuk?". Hermeneutik seperti ini penuh tantangan karena orangorang Kristen cenderung berpikir triumfalistik. ${ }^{29}$

$$
\text { PK “di balik dinding” juga }
$$
mencakup pemahaman dogma gereja dalam konteks mereka, konteks kontemporer. Dalam PK untuk perdamaian, umat Kristen perlu belajar "pasifisme", di satu sisi, dan "tradisi perang" di sisi lain, dalam perspektif historis dan etis. Mereka juga perlu belajar bagaimana Alkitab sering digunakan untuk membenarkan kekerasan (misalnya selama perang salib) dan sebaliknya, umat juga harus belajar nilainilai Kristen yang mendukung perdamaian, misalnya: pengampunan, rekonsiliasi, cinta kasih, keadilan, dan perdamaian. Di sisi lain, umat Kristen perlu belajar dari sejarah Indonesia untuk mencari akar konflik antara Muslim dan Kristen. Dengan demikian, umat Kristen akan memiliki suatu konteks untuk mengerjakan teologi kontekstual yang mempromosikan upaya perdamaian. PK "di balik dinding" ini mendukung PK "pada dinding" dan "melampaui dinding" 30 . Beberapa tahun yang lalu penulis ingat bahwa ketika konflik kerusuhan di Ambon,

30 Tabita Kartika Christiani, "Christian Education for Peace Building in the Pluralistic Indonesian Context, h. 185-187 
sebelum berperang atau sesudah berperang pastilah umat berdoa sebelum melakukan peperangan. Orang membunuh karena kondisi yang memaksakan. Jika tidak ada perlawanan itu berarti orang membiarkan agama, desanya dimusnahkan. Dari konteks seperti inilah umat perlu berefleksi kembali. Sejarah yang memiluhkan, meninggalkan bekas dalam ingatan umat karena kehilangan orang-orang yang dicintai.Umat perlu belajar mengampuni, mencintai dan melakukan rekonsiliasi. Sering juga teks-teks Alkitab membenarkan kekerasan. Teks-teks Alkitab ini jika tidak dimaknai orang pun akan melakukan kekerasan. Teks-teks Alkitab tidak bisa dibaca secara harafiah umat perlu berefleksi berdasarkan realitas yang majemuk.

PK seharusnya bukan hanya mengajarkan iman Kristen tetapi juga tentang agama lain. Ini penting untuk upaya perdamaian. Ini menuntun pada PK "pada dinding": kekristenan dalam dialog dengan umat beragama lain. Orang Kristen Indonesia perlu belajar tentang Islam, Budhisme, Hinduisme, Konfusianisme, dan tradisi lainnya. Secara khusus, mempelajari Islam adalah keharusan. Awalnya bisa

31 Tabita Kartika Christiani, "Christian Education for Peace Building in the Pluralistic Indonesian Context, p. 187-188

32 Tabita Kartika Kristiani . 2012. "Pendidikan Kristiani dengan Pendekatan diajarkan oleh guru Kristen yang memahami Islam tetapi lebih bagus lagi dari orang Islam sendiri. Umat Kristen akan ditolong untuk memahami dan menghargai mereka, juga mengatasi stigma, penilaian negatif, dan diskriminasi. Namun perlu disadari bahwa sikap diskriminatif juga sering terjadi di internal kekristenan sendiri. Misalnya, ketika melihat orang dari agama lain sebagai inferior atau bahkan penyembah berhala. Penginjilan untuk memenangkan jiwa bisa muncul dari sikap/perasaan seperti itu. ${ }^{31}$ Senada dengan itu, Christiani menegaskan perbedaan antara pluralisme dengan multikulturalisme. Pluralisme bermakna "merayakan perbedaan" sedang multikulturalisme lebih jauh lagi, yakni bermakna "perjuangan moral untuk memperoleh hak-hak kesetaraan dalam kedudukan dan peran sosial",32

"Pluralisme lunak berarti kita menyambut makanan etnik, pakaian etnik, dan musik etnik. Anda bisa menyantap sarapan pagi berupa masakan Cina, makan siang dengan menu Italia, dan makan malam dengan menu Prancis, tetapi kita tidak berbicara tentang kekuasaan politik dan ekonomi.... Pluralisme lunak tidak

Spiritualitas". Dalam Jozef Hehanusa dan Budyanto (ed.). Mendesain Ulang Pendidikan Teologi. (Yogyakarta: Duta Wacana University Press, 2012), p. 
berhadapan secara serius dengan kekuasaan dan pembedaan ekonomi dan politik. Saya menyebutnya pluralisme 'malas', lunak dan tak bermoral.... Saya pikir kita harus melampaui pluralisme. Kita membutuhkan transformasi yang saling bergantung, saling merembes, pembagian kekuasaan, dan timbal balik bagi kelangsungan dan pembebasan kita bersama serta bagi komunitas bumi yang berkesinambungan". 33

Dengan menimbang urgensi gerakan multikulturalisme, khususnya di Indonesia, para pakar pendidikan mendorong diselenggarakannya pendidikan multikulturalisme bagi masyarakat ${ }^{34}$. Menurut Panmilo Yangin, pendidikan multikulturalisme adalah: "Sebuah desain pendidikan yang dirancang secara sadar, dalam upaya penanaman cara hidup yang hormat, tulus, dan toleran terhadap keanekaragaman budaya yang hidup di tengah-tengah masyarakat plural. Pendidikan multikulturalisme diselenggarakan sebagai sarana melahirkan proses integrasi, yaitu upaya kolektif suatu masyarakat majemuk untuk mengelola berbagai prasangka sosial yang ada dengan cara-cara yang baik.” Pendidikan

33 Hope S. Anton, Pendidikan Kristiani Kontekstual, (Jakarta: BPK Gunung Mulia, 2010), p.124-125

${ }^{34}$ Panmilo Yangin, Gereja dan Pendidikan Multikultural: Pilar Pembangunan Masa Depan Indonesia. (Yogyakarta: Kanisius, 2010), p. 9 multikulturalisme sangat strategis untuk mengelola kemajemukan secara kreatif, sehingga konflik yang muncul sebagai dampak dari transformasi dan reformasi sosial dapat dikelola secara cerdas dan menjadi bagian dari pencerahan kehidupan bangsa ke depan. ${ }^{35}$

Partikular tidak harus menempatkan seseorang dalam posisi yang berlawanan dengan orang lain. Kesadaran Yesus mengenai partikularitas-Nya menghasilkan perhatian baru dan lebih positif terhadap perbedaan, memunculkan suatu hasrat utuk belajar dari perbedaan serta memunculkan suatu pemahaman terhadap diri sendiri melalui dan bersama orang lain. ${ }^{36}$ Yesus mempertimbangkan berbagai opsi untuk menghadapi permintaan tolong perempuan itu. Yesus membuka diri pada suatu pertukaran yang jujur dengan perempaun itu, mitra dialog-Nya, mendengarkan pandangan perempuan dan argumentasinya tandingannya. Dalam dialog yang jujur Yesus megambil resiko belajar dari perempuan yang akhirnya memang justru mengajari-Nya daa menginjili. Inilah opsi kerendahan dan keterbukaan terhadap orang lain.

\footnotetext{
${ }^{35}$ Panmilo Yangin, p. 27-28

36 Hope S. Anton, Pendidikan Kristiani Kontekstual, (Jakarta: BPK Gunung Mulia, 2010), h. 87
} 
Yangin menegaskan bahwa pendidikan agama juga harus berwawasan multikulturalisme. Wacana pendidikan multikulturalisme tidak berpretensi menghilangkan nilai-nilai partikular agama. Partikularitas suatu agama hanya diperuntukkan bagi pemeluk agama itu saja, dan tidak dipaksakan untuk pemeluk agama lain. Dalam menghadapi pemeluk agama yang berbeda, yang harus dipegang adalah nilai-nilai universal berupa keadilan, kemanusiaan, kesetaraan, berbuat baik dan melakukan kasih terhadap sesama, kejujuran, dan lain sebagainya. Dengan demikian, pendidikan multikulturalisme boleh dikatakan sebagai sebuah proses pengembangan sikap dan tata laku seseorang atau sekelompok orang dalam usaha mendewasakan manusia melalui upaya pengajaran, pelatihan, proses, perbuatan, dan cara-cara mendidik yang menghargai pluralitas dan heterogenitas secara humanistik. Diharapkan agar peserta didik memiliki karakter yang kuat untuk bersikap demokratis, pluralis, dan humanis 37

Banks mengidentifikasi empat pendekatan terhadap integrasi konten etnik dan multikultural ke dalam kurikulum. Pertama, Pendekatan Kontributif, dengan menempatkan pahlawan etnik, hari libur nasional tertentu, dan artifak kultural ke dalam kurikulum, diseleksi dengan menggunakan kriteria yang sama sebagaimana digunakan dalam menyeleksi pahlawan dan artifak mainstream Barat. Maka, nama-nama seperti Crispus Attucks, Benyamin Bannaker, dan Pocahontas ditambahkan dalam kurikulum. Elemen kultural seperti makanan khas, musik, tarian, dan artifak dari pelbagai kelompok dipelajari namun sedikit perhatian diberikan kepada makna-makna dan pentingnya bagi komunitas etnik. Dalam pendekatan kontributif, kurikulum mainstream tetap tidak berubah dalam hal struktur dasarnya, tujuan-tujuannya dan karakter-karakter yang menonjol. Seleksi terhadap pahlawan-pahlawan pun harus dengan syarat bahwa mereka harus memiliki peran dan kontribusi bagi masyarakat dan budaya AS. Individu yang berhasil mengubah ideologi, nilai-nilai, konsep-konsep dominan di masyarakat, dan yang mengadvokasi reformasi politik, sosial, dan ekonomi, jarang dimasukkan ke dalam pendekatan kontributif. Dalam pendekatan ini, konten etnik dibatasi pada hari-hari, minggu-minggu, dan bulan-bulan spesial yang terkait dengan perayaan etnik. Guru melibatkan siswa dalam pelajaran, pengalaman terkait perayaan kelompok etnik yang diperingati. Namun sedikit sekali belajar tentang kelompok etnik

${ }^{37}$ Panmilo Yangin, p. 42-43 
tersebut sebelum atau sesudah perayaan tersebut. Guru juga memiliki pengetahuan sedikit tentang kelompok etnik dan revisi kurikulum. $^{38}$

Kedua, Pendekatan Tambahan (Additive Approaches) berupa penambahan konten, konsep, tema, dan perspektif tanpa mengubah struktur, tujuan, dan karakter dasar. Guru mengajarkan konten etnik tetapi tanpa merestrukturisasinya. Pendekatan ini dapat menjadi fase pertama dalam suatu upaya reformasi kurikulum transformatif yang didesain untuk merestrukturisasi total kurikulum dan mengintegrasikannya dengan konten, perspektif, sudut pandangan, dan referensi etnis. Namun pendekatan ini masih memakai perspektif Barat dalam menyeleksi even, konsep, isu, dan problem etnik lain. Ketika mengajar tentang gerakan orang-orang Eropa yang melewati Amerika Utara, guru seharusnya menolong siswa memahami bahwa kelompok-kelompok yang berbeda kultur, ras, dan etnis sering memiliki konsep-konsep dan cara pandang yang bertentangan dan bervariasi tentang even sejarah, konsep, isu, dan pengembangan-pengembangan yang sama. Jika belajar dari semua perspektif, baik yang mainstream maupun yang lain, baik

38 James ABanks\& McgeeBanksCherry A (eds), Multicultural Education: Issues and Perspectives(New York: John Willey \&Sons, 2001), h. 299-231 yang menang dan kalah dalam peperangan, maka siswa akan memahami secara penuh sejarah, kultur, dan masyarakatnya. Pihak yang dikalahkan dan mengalahkan memiliki sejarah dan budaya yang berkaitan. Mereka belajar sejarah dan kultur satu sama lain sehingga memahami diri mereka secara penuh. Orang AS kulit putih tidak dapat memahami secara penuh sejarah AS tanpa memahami sejarah suku Indian dan bagaimana sejarah mereka berkaitan. Sayangnya pendekatan tambahan gagal dalam membantu siswa memandang masyarakat dari perspektif keragaman etnik dan budaya dan untuk memahami bagaimana sejarah dan budaya dari kelompok agama, budaya, ras, dan etnik saling berhubungan satu sama lain. ${ }^{39}$. Konten, materi, dan isu yang ditambahkan dalam kurikulum sebagai "lampiran" bisa menjadi problematik. Problem muncul ketika siswa kurang memahami emosi, latar belakang, dan konsep-konsep yang berhubungan dengan isu dalam materi tersebut. Penambahan konten etnik ke dalam kurikulum secara sporadis dan "hanya segmented" bisa menimbulkan persoalan dalam pedagogis, yakni kesusahan para guru, kebingungan para siswa, dan kontroversi komunitas ${ }^{40}$.

\footnotetext{
39 James ABanks\& McgeeBanksCherry A (eds) , 231-233

40 James ABanks\& McgeeBanksCherry A (eds), 233
} 
Ketiga, Pendekatan Transformatif, yang berbeda secara mendasar dari kedua pendekatan sebelumnya karena perspektif, struktur, dan tujuan dasar dari kurikulum diubah. Pendekatan ini mengubah asumsiasumsi dasar dari kurikulum dan memampukan siswa memandang persoalan-persoalan, tema-tema, isu-isu, dan konsep-konsep dari beberapa perspektif dan sudut pandang etnik. Perspektif mainstream hanyalah salah satu perspektif. Isu-isu kunci dalam reformasi kurikulum multikultural bukanlah penambahan daftar kelompok etnik, pahlawan, dan kontribusi, tetapi penyatuan integral berbagai perspektif dari berbagai kelompok yang memperluas siswa memahami sifat, pengembangan, dan kompleksitas masyarakat AS. Ketika topik soal musik, tarian, dan literatur dipelajari, guru memperkenalkan bentuk-bentuk kesenian tersebut di antara kelompok etnik AS yang kesemuanya memiliki pengaruh besar dan memperkaya tradisi literatur dan kesenian nasional. Ketika mempelajari sejarah, bahasa, musik, seni, ilmu, pengetahuan, dan matematika AS, penekanannya bukan pada kontribusi kelompok etnik, namun bagaimana masyarakat dan budaya AS sekarang ini muncul dari sintesa kompleks dan interaksi

\footnotetext{
41 James ABanks\& McgeeBanksCherry A (eds) , 233-235
}

dari berbagai elemen kultural yang orisinal dalam kelompok religi, etnik, ras, dan kultural yang menyusun masyarakat AS. Banks menyebut proses ini sebagai “akulturasi jamak”. Konsep ini menuntun kita pada suatu perpektif yang memandang even, literatur, musik, dan seni sebagai bagian integral dari kultur AS saat ini. Anglo-Saxon Protestan dipandang sebagai salah satu bagian dari keseluruhan kultur yang lebih besar. ${ }^{41}$

Keempat, Pendekatan Aksi Sosial, yang mencakup semua elemen pendekatan transformatif tetapi ditambah komponen yang mewajibkan siswa untuk membuat keputusan dan melakukan aksi terkait dengan konsep, isi, atau problem yang dipelajari. Tujuan besar dari instruksi dalam pendekatan ini adalah mendidik siswa untuk kritis dan menjadi pelaku perubahan sosial, serta mengajar mereka ketrampilan membuat keputusan. Untuk memberdayakan siswa, sekolah harus menolong mereka menjadi partisipan yang trampil dan kritis reflektif dalam perubahan sosial. Dalam pendekatan ini, guru adalah agen perubahan sosial yang mempromosikan nilai-nilai demokratis dan pemberdayaan bagi siswa ${ }^{42}$. Keempat pendekatan di atas sering bercampur dalam situasi aktual pengajaran. Pendekatan

\footnotetext{
(eds), 236
} 
kontributif misalnya, dapat digunakan seperti "mesin/kendaraan" yang mendorong pendekatan-pendekatan lainnya, seperti pendekatan transformasi dan aksi sosial. Adalah tidak realistis mengharapkan untuk langsung menerapkan dari pendekatan mainstream menuju kurikulum yang fokus pada aksi sosial. Pergerakan menuju level paling tinggi perlu proses gradual dan kumulatif. ${ }^{43}$

Semua teori pendidikan Kristiani multikultural yang dijelaskan oleh para ahli merupakan hal-hal yang dapat membantu kegiatan Pendidikan multikultural yang kurang diperhatikan di gereja. Gereja tidak bisa menjadi gereja pada "dinding" tetapi tidak "melampaui dinding". Gereja hadir di tengah keberagaman. Oleh karena itu gereja pun perlu mengembangkan pengajaran yang sesuai dengan konteks kemajemukan bukan pada hanya doktrin gereja saja. Gereja perlu mengembangkan pendidikan yang relevan dengan konteks Umat. Mengutamakan refleksi kritis dari umat terhadap teks-teks Alkitab. Menerima seluruh pengalaman umat bukan hanya berfokus pada tafsiran dari para ahli biblika.

\section{KESIMPULAN} (eds), 239
Dalam melihat akan teks bacaan Markus 7:24-30 Perbedaan-perbedaan seperti ras, budaya agama, etnis, bahkan dalam denominasi gereja sendiri merupakan isu-isu yang memacuh terjadinya kekerasan dalam konteks Indonesia. Padahal Yesus sediri terbuka terhadap keberadaan yang lain. Kasih Allah bukan hanya terjadi pada orang Yahudi saja tetapi lebih luas bahkan bagi mereka yang tidak percaya kepada-Nya sekalipun. Seorang pluralis bagaimanapun juga adalah seorang yang berakar dengan baik dalam tradisi imannya, tetapi terbuka dan mampu mengakui orang-orang yang berasal dari tradisi agama lain. Dialog sangat dibutuhkan untuk mengganti upaya-upaya kristenisasi yang dilakukan oleh gereja. Dialog merupkan cara untuk mengakui kebebasan orang lain sehingga ketika dihubungkan dengan Pendidikan multikulturalisme bukan semata menerima dan menghargai keberagaman tetapi juga merupakan gerakan moral untuk memperjuangkan nilai-nilai kesetaraan, pemberdayaan, dan keterlibatan peran semua elemen kultural di sebuah masyarakat yang beragam. Pendidikan multikultural bertujuan untuk menciptakan pendidikan yang setara bagi kelompok yang berbeda, baik dari latar belakang 
gender, ras, etnis, kelas sosial, bahasa, agama dan budaya.

\section{DAFTAR PUSTAKA}

Anton, Hope. S, Pendidikan Kristiani Kontekstual,Jakarta: BPK Gunung Mulia, 2010.

Banks James. A\& McgeeBanksCherry A(eds), Multicultural Education: Issues and Perspectives, New York: John Willey \&Sons, 2001.

Christiani, Tabita Kartika, Christian Education for Peace Building in the Pluralistic Indonesian Context, Zuric: LIT VERLAG, 2009.

Christiani, Tabita Kartika, Pendidikan Kristiani Berbasis Multikultural, Ungaran: Semarang, 2018.

Christiani, Tabita Kartika, "Pendidikan Kristiani dengan Pendekatan Spiritualitas". Dalam Jozef Hehanusa dan Budyanto (ed.). Mendesain Ulang Pendidikan Teologi, Yogyakarta: Duta Wacana University Press, 2012

Hurtado, Larry W, How on Earth Jesus Become God?Historical Questions about Earliest Devotion to Jesus, Grand Rapids, Michigan: Eerdmans, 2005.
Josephus , Against Apion, 1.70, in Josephus: The Complete Works, Grand Rapids, Michigan: Christian Classics Ethereal Library.

Kärkkäinen Veli-Matti, An Introduction to the Theology of Religions: Biblical, Historical, and Contemporary Perspectives, Downers Grove, Ill.: InterVarsity Press, 2003.

Seymour, Jack. L (ed), Memetakan Pendidikan Kristiani PendekatanPendekatan Menuju Pembelajaran Jemaat, Jakarta: BPK Gunung Mulia, 2016.

Yangin Panmilo, Gereja dan Pendidikan Multikultural: Pilar Pembangunan Masa Depan Indonesia. Yogyakarta: Kanisius, 2010. 